\title{
Elemental and mutational analysis of lung tissue in lung adenocarcinoma patients
}

\author{
Ryosuke Chiba $^{1}$, Naoto Morikawa ${ }^{1}$, Koichiro Sera ${ }^{2}$, Kazuyuki Ishida ${ }^{3}$, Hiromi Nagashima ${ }^{1}$, \\ Wataru Shigeeda ${ }^{4}$, Hiroyuki Deguchi ${ }^{4}$, Makoto Tomoyasu ${ }^{4}$, Takako Hosokawa ${ }^{5}$, Hajime Saito ${ }^{4}$, \\ Tamotsu Sugai ${ }^{3}$, Kohei Yamauchi ${ }^{1}$, Makoto Maemondo ${ }^{1}$
}

${ }^{1}$ Department of Internal Medicine, Division of Pulmonary Medicine, Allergy, and Rheumatology, Iwate Medical University School of Medicine Morioka, Iwate, Japan; ${ }^{2}$ Cyclotron Research Center, Iwate Medical University School of Medicine Takizawa, Iwate, Japan; ${ }^{3}$ Department of Molecular Diagnostic Pathology, ${ }^{4}$ Department of Thoracic Surgery, Iwate Medical University School of Medicine Morioka, Iwate, Japan; ${ }^{5}$ Takizawa Laboratory, Japan Radioisotope Association, Takizawa, Iwate, Japan

Contributions: (I) Conception and design: R Chiba, N Morikawa, K Yamauchi, M Maemondo; (II) Administrative support: None; (III) Provision of study materials or patients: H Nagashima, W Shigeeda, H Deguchi, M Tomoyasu, H Saito; (IV) Collection and assembly of data: None; (V) Data analysis and interpretation: R Chiba, N Morikawa; (VI) Manuscript writing: All authors; (VII) Final approval of manuscript: All authors.

Correspondence to: Naoto Morikawa. Department of Internal Medicine, Division of Pulmonary Medicine, Allergy, and Rheumatology, Iwate Medical University School of Medicine Morioka, Iwate, Japan. Email: carcinoma@nifty.com.

Background: This study aimed to observe the association between trace element concentrations in lung tissue from lung adenocarcinoma cancer (LADC) patients and mutations in the epidermal growth factor receptor $(E G F R)$ and $K R A S$ genes.

Methods: LADC patients who had undergone lung resection were included in this study. Furthermore, twenty patients without lung cancer were included in this study as the control group. Samples were separately collected from both tumor and peritumor tissues. The mutational status was assessed for EGFR mutations, ALK rearrangements and KRAS mutations. Based on these analyses, patients were grouped into three groups: EGFR mutation, KRAS mutation and wild-type groups. The concentrations of various trace elements in the lung tissues were measured by a particle-induced X-ray emission (PIXE) system, and the results were analyzed for statistical significance.

Results: A total of 110 LADC patients were included in this study. The median age was 70 years, and $60 \%$ of the participants were female. Moreover, $18 \%$ and $20 \%$ of patients were EGFR- and KRASpositive, respectively. Thirty-two trace elements were measured, and 18 trace elements were detectable. The concentrations of $\mathrm{Fe}, \mathrm{Co}, \mathrm{Ni}, \mathrm{Cu}, \mathrm{Zn}$ and $\mathrm{Br}$ were significantly higher in the KRAS mutation and wild-type groups than in the control group regardless of whether the samples were from tumor or peritumor tissues. For these 6 trace elements, the concentrations were significantly higher in smokers than in non-smokers. Considering the effect of smoking, differences in the trace element concentrations between each mutational group remained.

Conclusions: Trace elements in the lung may play a role in development of LADC in both smokers and never-smokers. However, prospective studies with larger sample sizes are needed to support this hypothesis.

Keywords: Trace element; lung cancer; adenocarcinoma; driver mutation

Submitted Aug 11, 2019. Accepted for publication Aug 20, 2019.

doi: $10.21037 /$ tlcr.2019.08.18

View this article at: http://dx.doi.org/10.21037/tlcr.2019.08.18 


\section{Introduction}

Lung cancer mortality is the leading cause of cancer death in both men and women worldwide (1). Non-small cell lung cancer (NSCLC) represents $85 \%$ of all lung cancers and has a 5 -year survival rate of $4 \%$ in patients with metastasis (2). This situation has been improved by development of driver mutations in tumor and molecular targeting therapy adapting these mutations (3-6). Epidermal growth factor receptor (EGFR), v-Ki-ras2 Kirsten rat sarcoma viral oncogene (KRAS), and anaplastic lymphoma kinase (ALK) are the most commonly mutated oncogenes that serve as genetic drivers involved in the pathogenesis of lung cancer. Several selective EGFR tyrosine kinase inhibitors (TKIs) and an ALK inhibitor are effective as targeted therapies in patients who harbor those driver mutations $(5,7)$. According to guidelines, mutation analysis of both EGFR and ALK is recommended regarding cost-effectiveness of genetic screening (8). Both EGFR mutations and ALK rearrangements play an important role in carcinogenesis through their involvement in the modulation of several pathways, including cell proliferation, apoptosis, and neovascularization pathways, via activation and/or enhancement of tyrosine kinase activity (9). However, the mechanism of tumor formation harboring driver mutations is currently unclear.

The epidemiology of lung cancer in patients without a history of smoking is still unknown, but some risk factors have been well determined, including passive exposure of tobacco smoke and working in certain occupations. Exposure to some environmental elements plays an important role in development of lung cancer. Previously published studies have suggested that radon is an element that correlates the risk factor for lung cancer in neversmokers $(10,11)$. However, clear mechanism of development of lung cancer by radon has not been elucidated.

Previous research findings have indicated that the molecular profile of lung cancer varies according to carcinogen exposure history; therefore, the biological pathways of lung cancer in never-smokers are different from those in ever-smokers $(12,13)$.

Trace elements are one of the risk factors of some kinds of cancers. A full understanding of trace element speciation, localization and function under various pathophysiological conditions is becoming increasingly important for understanding disease mechanisms and determining novel diagnostic, prognostic, and therapeutic targets for breast cancer (14). Urinary trace elements in patients with renal cell carcinoma differ from those in healthy individuals (15). Little is known about the beneficial or harmful relationships between trace element levels and cancer.

This study used particle-induced $\mathrm{X}$-ray emission (PIXE) to detect trace elements in surgically resected lung adenocarcinoma cancer (LADC) tissues and healthy control tissues (Figure S1). PIXE analysis has been used in the investigation of the elemental nature of complicated structures, such as human tissue sections, and provides elemental composition and trace concentrations for most elements with high sensitivity. We reported that PIXE analysis is a powerful tool for the elemental analysis of tissue samples (16-18).

Thus, we sought to determine whether there is an association between trace element concentrations in the lung tissue of patients with EGFR or KRAS mutations.

\section{Methods}

\section{Patient population}

Between January 2013 and December 2016, 1,157 patients who had undergone surgical resection at Iwate Medical University Hospital were screened.

All primary diagnoses were reviewed by experienced pathologists at each site according to the World Health Organization (WHO) nomenclature for adenocarcinoma. Specimens chosen for analysis were from patients with a confirmed diagnosis of LADC and tumors measuring greater than $20 \mathrm{~mm}$, and tumor regions having more than $70 \%$ tumor cells were utilized. Data collected from each case including age, sex, smoking history, and tumornode-metastasis (TNM) stage. Formalin-fixed paraffinembedded (FFPE) clinical tissue blocks were corrected for immunohistochemistry (IHC) and mutational status analyses. Based on hematoxylin and eosin staining, an additional block with less than $5 \%$ tumor cellularity from the same patient diagnosed with a tumor was used as the peritumor sample. Tissues from 20 patients with nonmalignant diseases (e.g., pneumothorax) were used as controls.

This study was conducted according to the provisions of the Helsinki Declaration and approved by the Ethics Committee at the Iwate Medical University School of Medicine (H26-70), and all participants signed written consent forms before participating in the research.

\section{Mutational status analysis}

Tumor samples from the enrolled patients were collected. Tumor tissues were obtained as FFPE samples in 5- $\mu$ m-thick sections on glass slides from patients whose samples were 
Table 1 Patient characteristics

\begin{tabular}{|c|c|c|c|c|c|}
\hline Characteristics & $\begin{array}{l}\text { Control } \\
(n=20)\end{array}$ & $\begin{array}{c}\text { LADC all } \\
(n=110)\end{array}$ & $\begin{array}{c}\text { EGFR } \\
\text { mutation } \\
(n=20)\end{array}$ & $\begin{array}{c}\text { KRAS } \\
\text { mutation } \\
(n=32)\end{array}$ & $\begin{array}{c}\text { Wild } \\
\text { type } \\
(n=58)\end{array}$ \\
\hline $\begin{array}{l}\text { Age (years), } \\
\text { median [range] }\end{array}$ & $\begin{array}{c}63 \\
{[27-79]}\end{array}$ & $\begin{array}{c}70 \\
{[45-96]}\end{array}$ & $\begin{array}{c}70 \\
{[50-80]}\end{array}$ & $\begin{array}{c}71.5 \\
{[60-86]}\end{array}$ & $\begin{array}{c}73.5 \\
{[54-85]}\end{array}$ \\
\hline \multicolumn{6}{|l|}{ Sex } \\
\hline Female & 9 & 66 & 13 & 11 & 42 \\
\hline Male & 11 & 44 & 7 & 21 & 16 \\
\hline \multicolumn{6}{|l|}{ Smoking history } \\
\hline Never & 10 & 60 & 20 & 10 & 30 \\
\hline Ever/current & 10 & 50 & 0 & 22 & 28 \\
\hline \multicolumn{6}{|l|}{ Stage } \\
\hline $1 / 2$ & - & 97 & 19 & 31 & 47 \\
\hline $3 / 4$ & - & 13 & 1 & 1 & 11 \\
\hline \multicolumn{6}{|l|}{ EGFR mutation } \\
\hline Ex19 & - & 14 & 14 & 0 & 0 \\
\hline Ex21 & - & 6 & 6 & 0 & 0 \\
\hline Negative & - & 90 & 0 & 32 & 58 \\
\hline \multicolumn{6}{|c|}{ ALK rearrangement } \\
\hline Positive & - & 0 & 0 & 0 & 0 \\
\hline Negative & - & 110 & 20 & 32 & 58 \\
\hline \multicolumn{6}{|l|}{ KRAS mutation } \\
\hline Positive & - & 32 & 0 & 32 & 0 \\
\hline Negative & - & 58 & 0 & 0 & 58 \\
\hline NA & - & 20 & 20 & 0 & 0 \\
\hline
\end{tabular}

LADC, lung adenocarcinoma cancer; NA, not applicable.

available. For KRAS and EGFR gene mutation analyses, the tissues were removed from the slides by scraping, and DNA was extracted from the tissues. KRAS mutations of codons 12 and 13 were detected using the Scorpion-ARMS method (19). The EGFR gene status was analyzed using the cycleave PCR method for exon 18 G719X, exon 20 T790M, and exon $21 \mathrm{~L} 858 \mathrm{R} / \mathrm{L} 861 \mathrm{Q}$ and the fragment method for exon 19 deletion (other than the PNA-LNA PCR clamp method) (20). ALK fusion protein status was analyzed using a Histofine ${ }^{\circledR}$ ALK detection kit (Tokyo, Japan).

Based on these analyses, patients were grouped into three groups, which included the EGFR mutation, KRAS mutation and wild-type groups, for triple negative EGFR mutations, ALK rearrangements and KRAS mutations.

\section{PIXE analysis}

Untreated organ samples weighing less than $50 \mu \mathrm{g}$ were placed on a backing film (4- $\mu \mathrm{m}$-thick Proline film) and fixed with $1 \%$ collodion solution, and the samples were quantitatively analyzed based on the standard-free method for untreated organs.

A 2.9 $\mathrm{MeV}$ proton beam extracted from a cyclotron at Nishina Memorial Cyclotron Center (NMCC) was transported to a PIXE vacuum chamber in a PIXE room and irradiated the targets. Emitted $\mathrm{X}$-rays were simultaneously measured with two $\mathrm{Si}(\mathrm{Li})$ detectors. X-ray absorbers (300- $\mu$ m-thick Mylar films) were used for the No. 1 detector, while an $\mathrm{X}$-ray collimator consisting of graphite with an aperture of $1.5 \mathrm{~mm}$ in diameter was placed directly in front of detector No. 2 to adjust the counting rate of the $\mathrm{X}$-rays. The typical beam current in the vacuum chamber was approximately $70 \mathrm{nA}$, and the spot size of the beam was $5 \mathrm{~mm}$ in diameter. A more detailed description of the arrangement is provided in a previous publication (21).

\section{Statistical analysis}

For all experiments, statistical analysis was performed using Prism 7.03 software (GraphPad Software, CA, US). P values were determined using the Kruskal-Wallis test and MannWhitney test. For all comparisons, $\mathrm{P}<0.05$ was considered statistically significant.

\section{Results}

This study included 110 patients with LADC; 66 patients $(60 \%)$ were females, and the median age of the patients was 70 years (range, 45-96 years). All patients were Japanese. Twenty samples from patients with a noncancerous disease (e.g., pneumothorax) were used as a control and compared with LADC samples. Twenty samples from patients having EGFR mutations restricted to exon 19 deletion and L858R point mutation and thirty-two samples from patients harboring KRAS mutations were collected for this study, and detailed mutational types of KRAS mutations are shown in Table S1. A detailed description of patient characteristics is shown in Table 1.

Figure 1 shows concentrations of trace elements in tumor tissue, peritumor tissue and control samples. The concentrations of a total of 32 trace elements were evaluated, and the concentrations of 14 out of the 32 trace elements were less than detection sensitivity. 


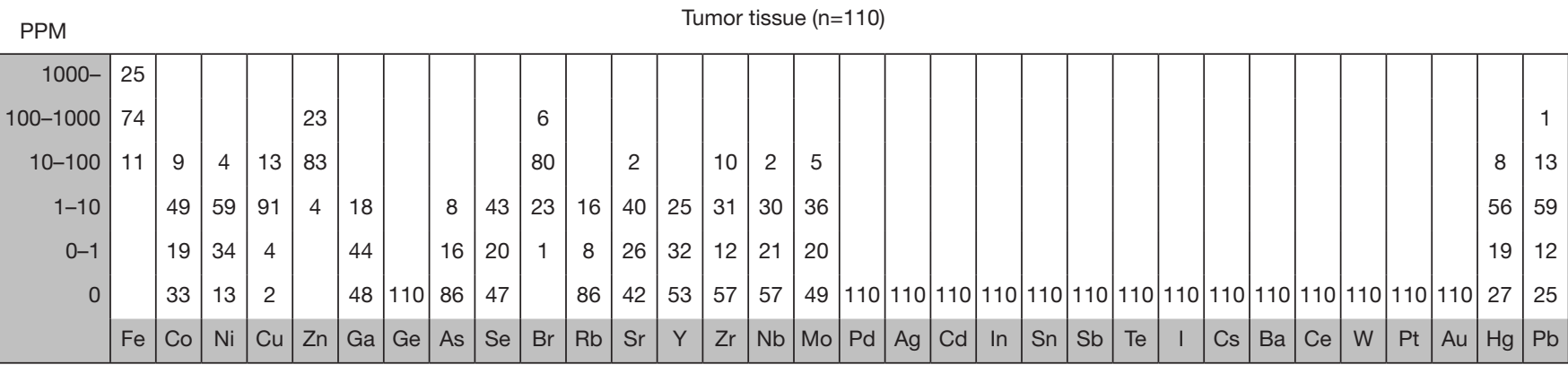

PPM

Peri-tumor tissue $(\mathrm{n}=110)$

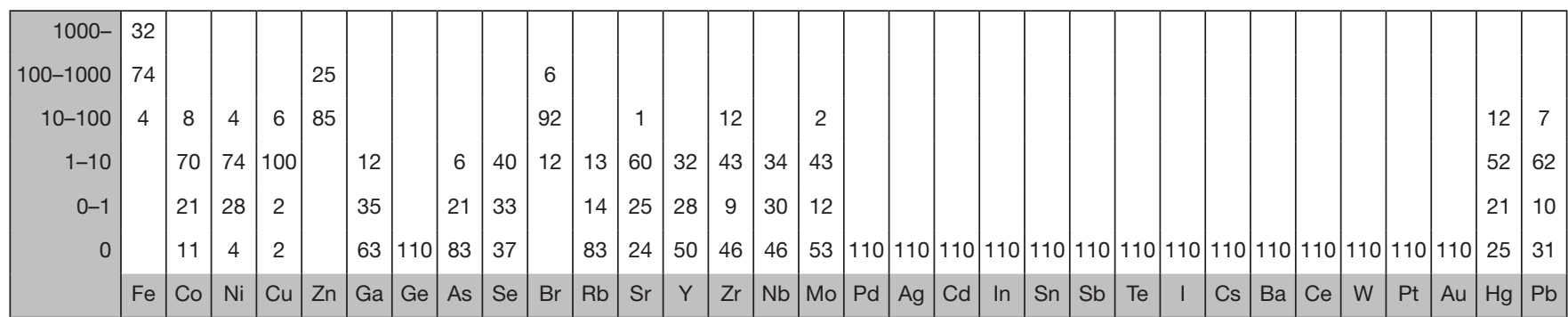

PPM

Control $(n=20)$

\begin{tabular}{|c|c|c|c|c|c|c|c|c|c|c|c|c|c|c|c|c|c|c|c|c|c|c|c|c|c|c|c|c|c|c|c|c|}
\hline $1000-$ & & & & & & & & & & & & & & & & & & & & & & & & & & & & & & & & \\
\hline $100-1000$ & 12 & & & & & & & & & & & & & & & & & & & & & & & & & & & & & & & \\
\hline $10-100$ & 7 & & & 1 & 17 & & & & & 2 & & & & & & & & & & & & & & & & & & & & & & 1 \\
\hline $1-10$ & 1 & & 5 & 14 & 3 & & & & 2 & 16 & 2 & 4 & 2 & 6 & 3 & 8 & & & & & & & & & & & & & & & 7 & 17 \\
\hline $0-1$ & & 2 & 10 & 5 & & 11 & & 7 & 4 & 1 & 3 & 11 & 9 & 9 & 10 & 3 & & & & & & & & & & & & & & & 8 & 2 \\
\hline 0 & & 18 & 5 & & & 9 & 20 & 13 & 14 & 1 & 15 & 5 & 9 & 5 & 7 & 9 & 20 & 20 & 20 & 20 & 20 & 20 & 20 & 20 & 20 & 20 & 20 & 20 & 20 & 20 & 5 & \\
\hline & $\mathrm{Fe}$ & Co & $\mathrm{Ni}$ & $\mathrm{Cu}$ & $\mathrm{Zn}$ & $\mathrm{Ga}$ & $\mathrm{Ge}$ & As & $\mathrm{Se}$ & $\mathrm{Br}$ & $\mathrm{Rb}$ & $\mathrm{Sr}$ & $Y$ & $\mathrm{Zr}$ & $\mathrm{Nb}$ & Mo & $\mathrm{Pd}$ & $\mathrm{Ag}$ & $\mathrm{Cd}$ & In & Sn & $\mathrm{Sb}$ & $\mathrm{Te}$ & I & Cs & $\mathrm{Ba}$ & $\mathrm{Ce}$ & W & $\mathrm{Pt}$ & $\mathrm{Au}$ & $\mathrm{Hg}$ & $\mathrm{Pb}$ \\
\hline
\end{tabular}

Figure 1 Amount of trace elements in the tissues of LADC patients and control patients. LADC, lung adenocarcinoma cancer.

Figure $2 A$ shows trace element concentrations in the control and LADC tumor samples grouped by EGFR mutation, K-Ras mutation, and wild type from lung cancer without driver mutations. The concentrations of 6 trace elements, including iron $(\mathrm{Fe})$, cobalt $(\mathrm{Co})$, nickel $(\mathrm{Ni})$, copper $(\mathrm{Cu})$, zinc $(\mathrm{Zn})$ and bromine $(\mathrm{Br})$, were significantly higher in the KRAS mutation group and wild-type group than in the control group but were not significantly different in the EGFR mutation group. Similarly, the concentrations of those 6 elements in the peritumor tissues that are supposed to be influenced by environmental exposure were significantly higher in the KRAS mutation group and wildtype group compared with the control group. Only Co was significantly higher in the EGFR mutation group than in the other groups among the peritumor samples (Figure 2B).

Next, we focused on the effect of smoking on tumor and peritumor tissues in terms of the 6 previously mentioned trace elements ( $\mathrm{Fe}, \mathrm{Co}, \mathrm{Ni}, \mathrm{Cu}, \mathrm{Zn}$ and $\mathrm{Br}$ ) because smoking affects some trace element concentrations $(22,23)$. The concentrations of these 6 trace elements were significantly increased in the KRAS mutation group and the wild-type group compared with the control group. The concentrations of these trace elements were significantly higher in samples from patients with a smoking history than in samples from patients without a smoking history both in tumor (Figure 3A) and peritumor tissues (Figure 3B). These data show the relationship between smoking history and trace element concentrations.

Based on these data, we analyzed trace element concentrations in tissues from patients with smoking history or not. In non-smokers, the concentrations of trace elements in the EGFR mutation, KRAS mutation and wild- 
A
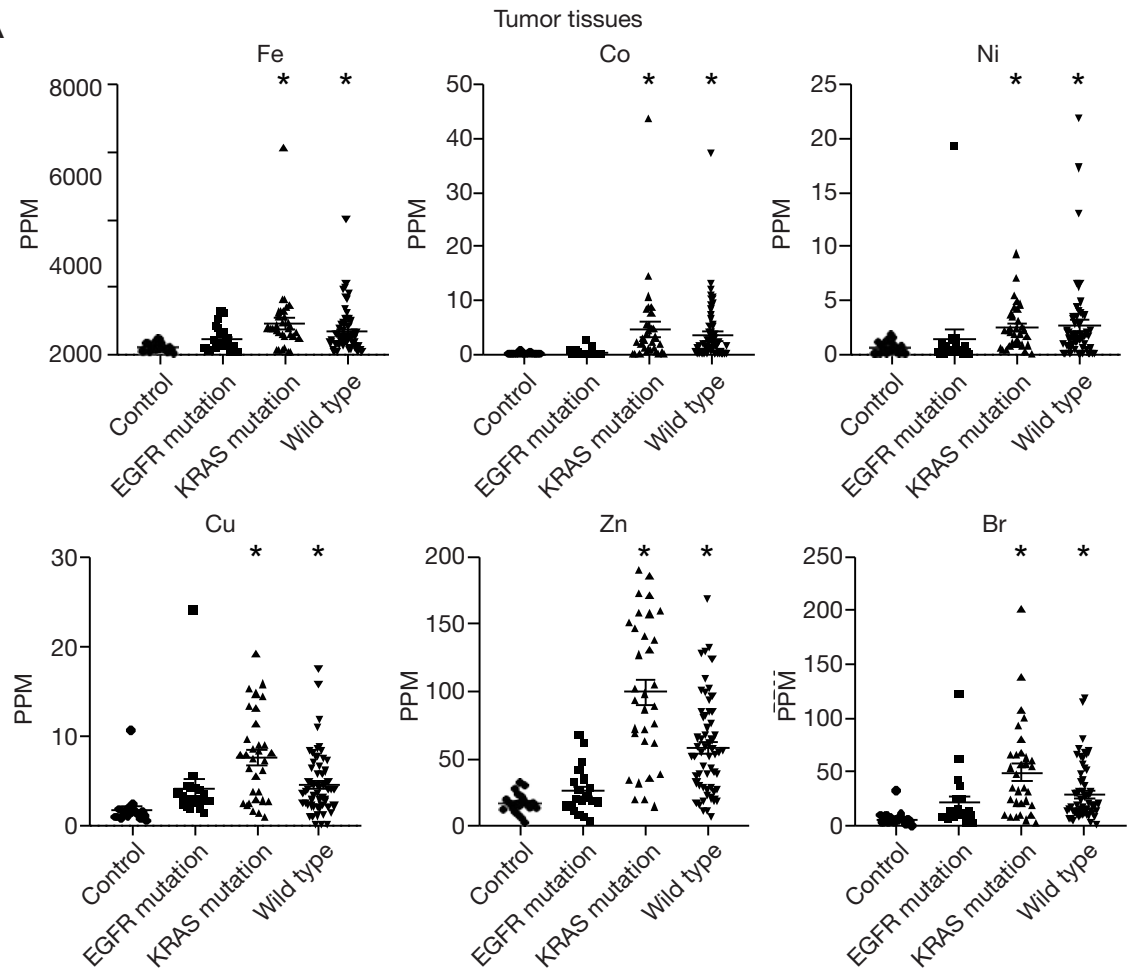

B

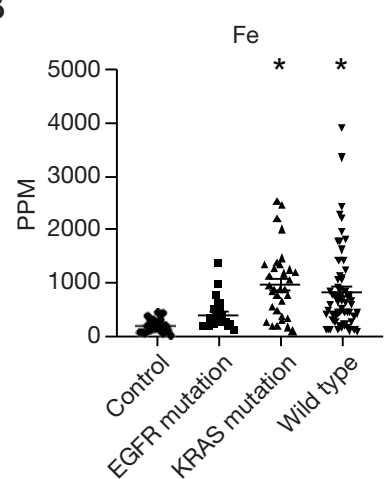

Peri-tumor tissues
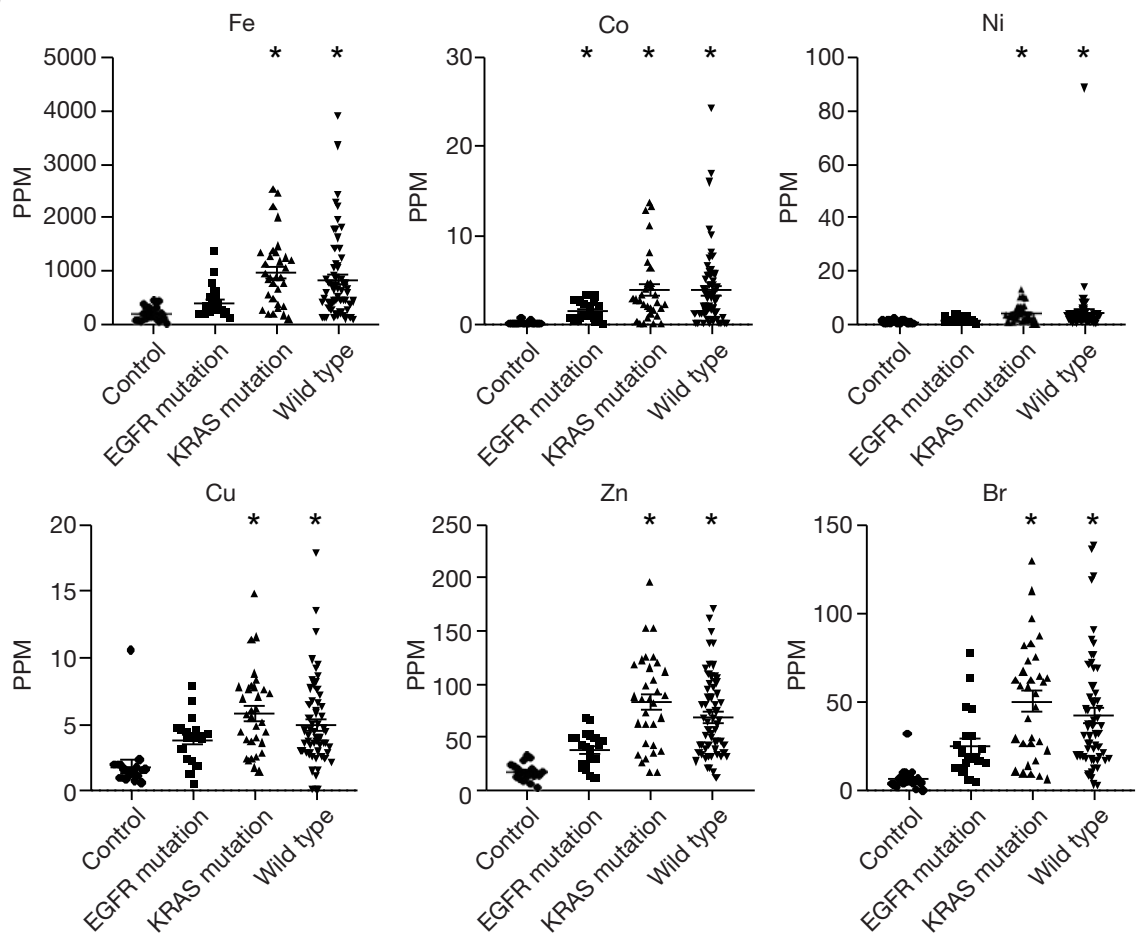

Figure 2 Comparison of trace element levels between LADC patients and control patients. (A) Illustrates the concentrations of Fe, Co, Ni, $\mathrm{Cu}, \mathrm{Zn}$, and $\mathrm{Br}$ measured in tumor tissues; (B) illustrates the concentrations of these elements in peritumor tissues. Each point illustrates an individual sample value, and the bold horizontal line in each group plot depicts the mean for each population. Asterisks indicate statistically significant differences compared to the control group $\left({ }^{*} \mathrm{P}<0.05\right)$. Fe, iron; Co, cobalt; Ni, nickel; $\mathrm{Cu}$, copper; $\mathrm{Zn}$, zinc; Br, bromine; $\mathrm{PPM}$, parts per million; LADC, lung adenocarcinoma cancer. 
A

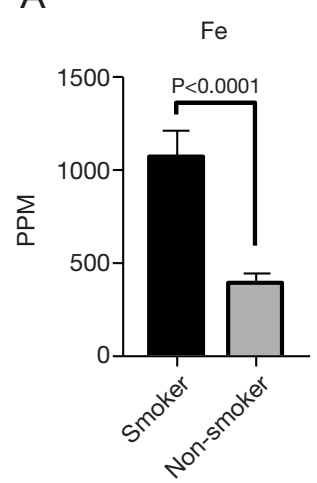

$\mathrm{Cu}$

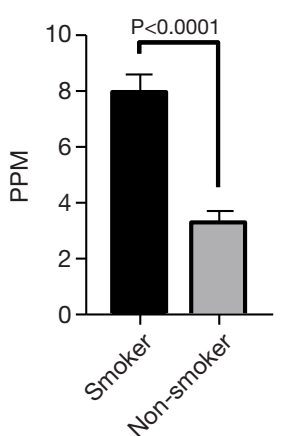

Tumor tissues

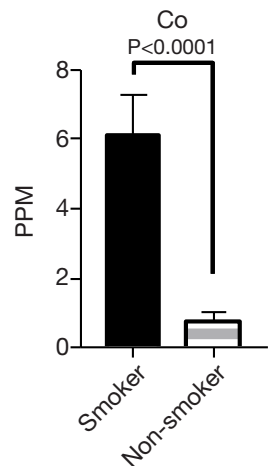

$\mathrm{Zn}$

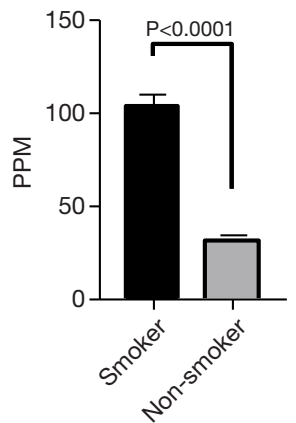

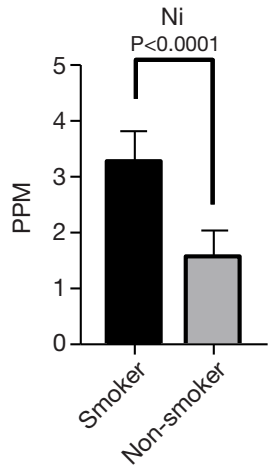

$\mathrm{Br}$

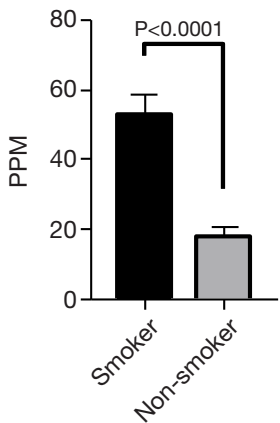

B

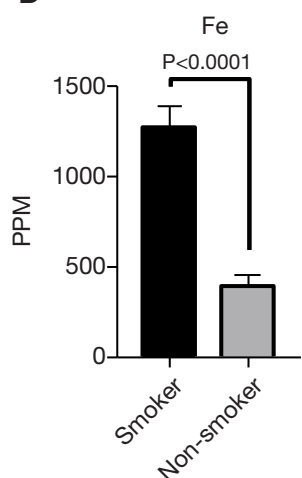

$\mathrm{Cu}$

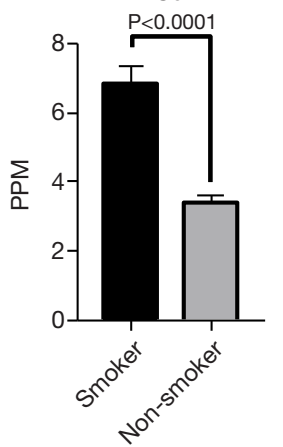

Peri-tumor tissues
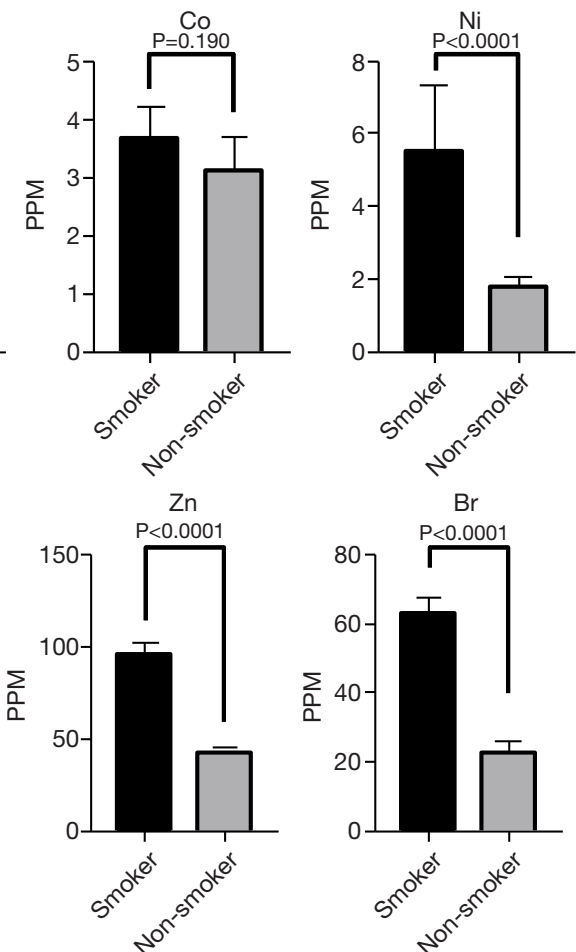

$\mathrm{Br}$

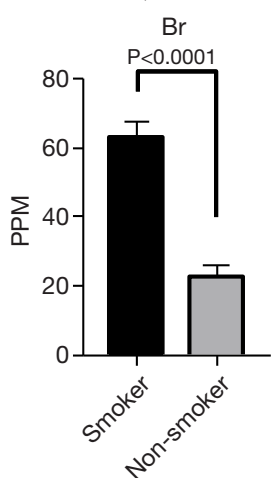

Figure 3 Trace elements in specimens of LADC patients exhibit significant differences between smokers and non-smokers. (A) Tumor tissues; (B) peri-tumor tissues. Data are presented as the mean \pm SEM. Fe, iron; Co, cobalt; Ni, nickel; Cu, copper; $\mathrm{Zn}$, zinc; Br, bromine; PPM, parts per million; SEM, standard error of the mean; LADC, lung adenocarcinoma cancer.

type groups frequently increases compared to those in the control group. The difference between EGFR and K-RAS or wild type disappeared (Figure 4). However, in smokers group, excluding patients with EGFR mutation who were non-smokers, the concentrations of these trace elements were significantly higher in the KRAS mutation and wildtype groups than in the control group in both tumors and peritumor tissues (Figure 5). These data suggest that smoking have more effect on tumor and peritumor tissue than the mutation status.

\section{Discussion}

To the best of our knowledge, this is the first study to evaluate trace element in tumor and peritumor tissue of lung cancer patients with driver mutations or not. Before initiation of this study, we had speculated that elemental findings might help elucidate etiology of driver mutations. In this study, it was found that increase of trace element is more associated with smoking status. In non-smokers of lung cancer, existence of driver mutation.

Both $E G F R$ mutations and $A L K$ gene rearrangements are more common in never-smoking LADC patients especially in Asian (3-6). Previous studies have focused on the possible effect of residential radon on gene alterations of EGFR and ALK. These studies evaluated relationship between residual radon concentrations and driver gene status. Taga, Mezquita, Ruano-Ravina studied factors including radon focusing on the EGFR gene, ALK rearrangements, and both the EGFR gene and ALK rearrangements, respectively (24-26). These studies showed a statistical relationship between residual radon concentrations and the prevalence of driver gene mutations. High radon exposure might provide a plausible explanation for the influence of radon on alterations of driver genes, but this phenomenon cannot be fully explained. Unfortunately, this PIXE system could not evaluate radon having a short half-time in the body.

In this study, we observed significant differences in the concentrations of 6 trace elements, including $\mathrm{Fe}, \mathrm{Co}, \mathrm{Ni}$, 

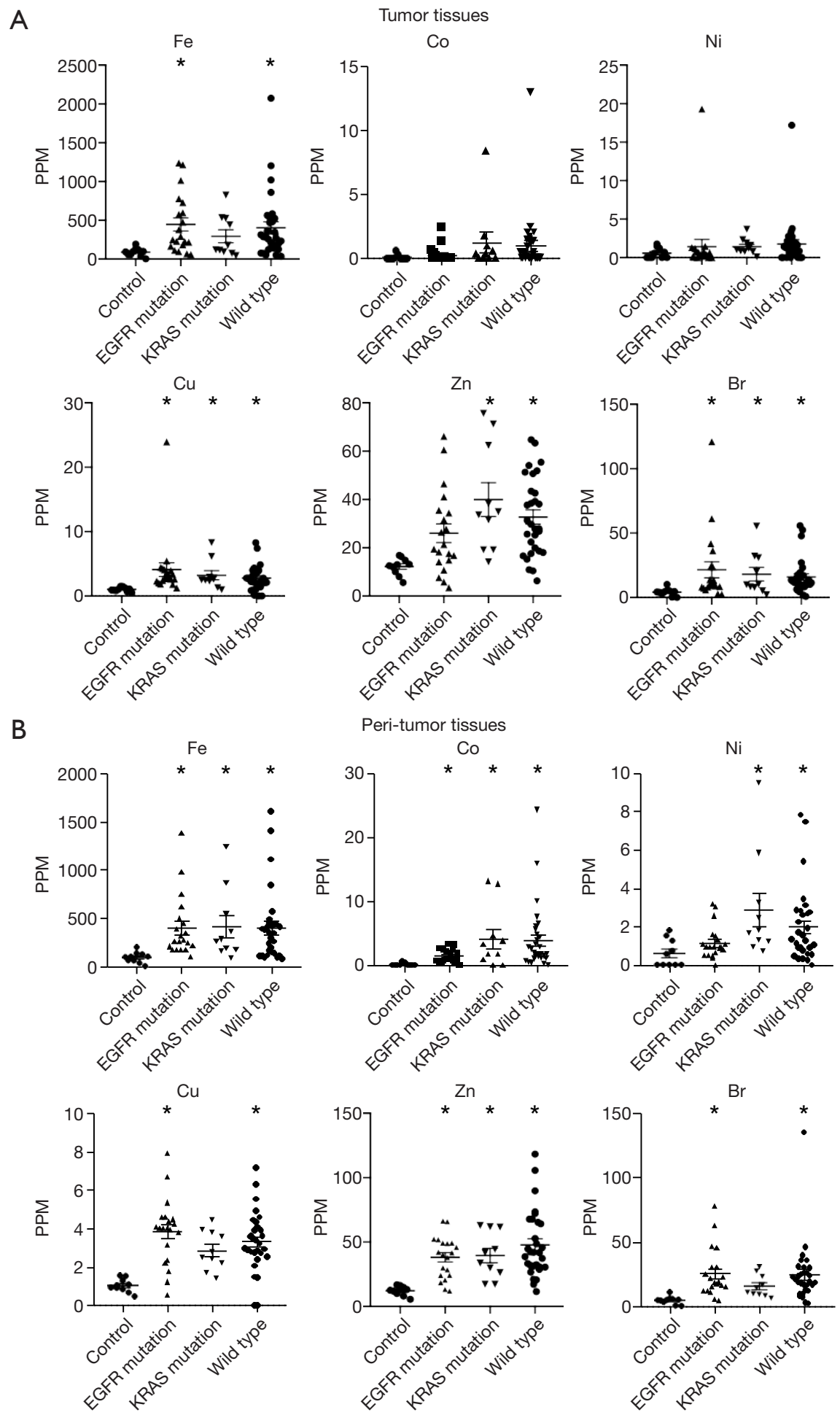

Figure 4 Comparison of trace element levels between LADC patients without a smoking history and control patients. (A) Illustrates the concentrations of $\mathrm{Fe}, \mathrm{Co}, \mathrm{Ni}, \mathrm{Cu}, \mathrm{Zn}$, and $\mathrm{Br}$ measured in tumor tissues; (B) illustrates the concentrations of these elements in peritumor tissues. Each point illustrates an individual sample value, and the bold horizontal line in each group plot depicts the mean for each population. Asterisks indicate statistically significant differences compared to the control group $\left({ }^{*} \mathrm{P}<0.05\right)$. Fe, iron; Co, cobalt; Ni, nickel; $\mathrm{Cu}$, copper; Zn, zinc; Br, bromine; PPM, parts per million; LADC, lung adenocarcinoma cancer. 

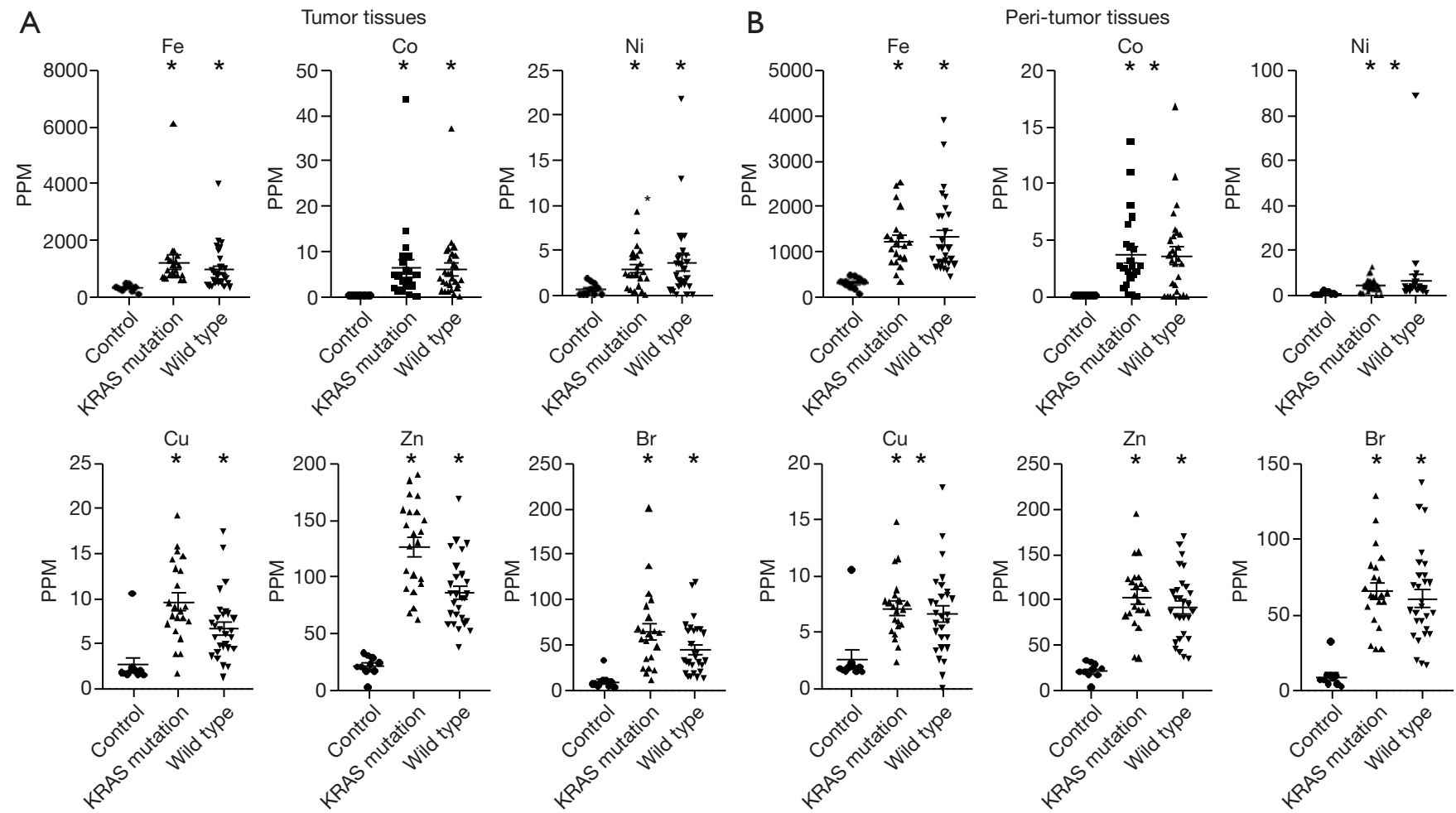

Figure 5 Comparison of trace element levels between LADC patients with a smoking history and control patients. (A) Illustrates the concentrations of $\mathrm{Fe}, \mathrm{Co}, \mathrm{Ni}, \mathrm{Cu}, \mathrm{Zn}$, and $\mathrm{Br}$ measured in tumor tissues; (B) illustrates the concentrations of these elements in peritumor tissues. Each point illustrates an individual sample value, and the bold horizontal line in each group plot depicts the mean for each population. Asterisks indicate statistically significant differences compared to the control group ( $\left.{ }^{*} \mathrm{P}<0.05\right)$. Fe, iron; Co, cobalt; Ni, nickel; $\mathrm{Cu}$, copper; Zn, zinc; Br, bromine; PPM, parts per million; LADC, lung adenocarcinoma cancer.

$\mathrm{Cu}, \mathrm{Zn}$ and $\mathrm{Br}$, between tissues from the non-cancer control group and the KRAS mutation/wild-type LADC groups. For these trace elements, each element has the potential for carcinogenesis or increasing the rate of cancer progression. Iron $(\mathrm{Fe})$ induces carcinogenesis through iron-catalyzed oxidative DNA damage (27). Epidemiological studies have shown that asbestos fibers containing $\mathrm{Fe}$ (a transition metal that catalyzes free radical generation) are highly carcinogenic (28). Observations have indicated that soluble cobalt (Co) cations affect genotoxic and carcinogenic activity in vitro and in vivo (29). Experimental data have indicated the genotoxic potential of Co in human lymphocytes (30). Nickel (Ni)/Ni compounds have carcinogenic potential through a chromosomal damage mechanism $(31,32)$. Research in this field has allowed for the identification of putative Ni targets relevant to carcinogenesis and the prediction of pathogenic effects caused by exposure to $\mathrm{Ni}$ (33). Copper $(\mathrm{Cu})$ is believed to play a central role in the formation of reactive oxygen species (ROS) that bind to DNA and cause damage by breaking DNA strands or modifying bases and/or deoxyribose, which leads to carcinogenesis $(34,35)$. The metabolic requirements of lung cancer cells for Zinc ( $\mathrm{Zn}$ ) are significantly greater than those of healthy cells; hence, this metabolic requirement may be the reason for increased uptake of $\mathrm{Zn}$ from blood (36). The concentrations of $\mathrm{Zn}$ are elevated in lung cancer tissues compared to normal tissues (37). Bromine (Br) compounds cause oxidative DNA damage (38), and bromate exposure might increase the risk of cancer in humans (39). Furthermore, the combined assessment of these trace elements might affect the redox status of lung cancer patients. Zabłocka-Słowińska et al. reported that a disturbed redox status in lung cancer patients is linked with alterations in $\mathrm{Zn}, \mathrm{Mn}$ and $\mathrm{Cu}$ trace element status (40). Overall, these trace elements have the potential for carcinogenesis of some lung cancer subtypes, and restricting the intake of these elements might be considered as one of effective strategies for cancer prevention. However, further investigations are 
required to explain these relationships clearly.

Smoking is considered an important source of inorganic trace elements, most of which are toxic to humans and are carcinogenic. Previously published literature has revealed that smoking tobacco influences the concentrations of several elements, such as $\mathrm{Al}, \mathrm{As}, \mathrm{Cd}, \mathrm{Cr}, \mathrm{Cu}, \mathrm{Pb}, \mathrm{Mn}, \mathrm{Hg}$, $\mathrm{Ni}, \mathrm{Po}, \mathrm{Se}$, and $\mathrm{Zn}$, in organs (41). Cigarette smokers have higher concentrations of $\mathrm{Cu}$ and $\mathrm{Zn}$ in the blood than non-smokers (42). Smoking affects Fe metabolism, which increases the concentration of Fe in liver tissue. Increased $\mathrm{Ni}$ and $\mathrm{Zn}$ concentrations have been shown to be correlated with smoking habits (43). Serum concentrations of $\mathrm{Co}, \mathrm{Cu}$, and $\mathrm{Fe}$ are elevated in patients with chronic obstructive pulmonary disease (COPD) and a smoking history (44). In the present study, we observed higher concentrations of Fe, $\mathrm{Co}, \mathrm{Ni}, \mathrm{Cu}, \mathrm{Zn}$ and $\mathrm{Br}$ in lung tissue from smokers than from never-smokers.

Many studies have suggested that the KRAS mutation is closely associated with cigarette smoking and EGFR mutation is related to non-smoker. It has been reported that NSCLC patients with a smoking history have a higher frequency of KRAS mutation than with never-smokers $(45,46)$. In this study, the KRAS mutation group showed a pattern of elevated trace element concentrations similar to that of the wildtype group. It suggested influence of smoking on both groups. However, comparing restricted to non-smoker, K-RAS mutation, EGFR mutation and wild type groups all show higher trace elements especially in peritumor tissue. Trace elements might play some role in development or promotion of lung cancer even in nonsmoker.

The strength of the current study is that trace elements in lung tissue were evaluated by PIXE system. In previous studies, measurements of trace elements were performed in serum or urine but not in lung tissue $(36,40,44)$. Limitations of this study include a small sample size, retrospective study design, and a lack of detailed biological data to support our hypothesis. Additionally, this study was limited to adenocarcinoma. A prospective trial could allow us to assess more trace elements with a short half-life such as radon.

\section{Conclusions}

In conclusion, trace elements in lung cancer tissue and peritumor tissue may play a role in the development of LADC in both smokers and never-smokers. However, more studies, such as prospective studies with larger sample sizes, are needed to support this hypothesis.

\section{Acknowledgments}

We thank the patients and their families as well as all of the investigators.

\section{Footnote}

Conflicts of Interest: The authors have no conflicts of interest to declare.

Ethical Statement: The authors are accountable for all aspects of the work in ensuring that questions related to the accuracy or integrity of any part of the work are appropriately investigated and resolved. This study was approved by the Ethics Committee at the Iwate Medical University School of Medicine (H26-70), and all participants signed written consent forms before participating in the research.

\section{References}

1. Torre LA, Bray F, Siegel RL, et al. Global cancer statistics, 2012. CA Cancer J Clin 2015;65:87-108.

2. Cetin K, Ettinger DS, Hei YJ, et al. Survival by histologic subtype in stage IV non-small cell lung cancer based on data from the surveillance, epidemiology and end results program. Clin Epidemiol 2011;3:139-48.

3. Lynch TJ, Bell DW, Sordella R, et al. Activating mutations in the epidermal growth factor receptor underlying responsiveness of non-small-cell lung cancer to gefitinib. N Engl J Med 2004;350:2129-39.

4. Riely GJ, Marks J, Pao W. KRAS mutations in non-small cell lung cancer. Proc Am Thorac Soc 2009;6:201-5.

5. Kwak EL, Bang YJ, Camidge DR, et al. Anaplastic lymphoma kinase inhibition in non-small-cell lung cancer. N Engl J Med 2010;363:1693-703.

6. Soda M, Choi YL, Enomoto M, et al. Identification of the transforming EML4-ALK fusion gene in non-small-cell lung cancer. Nature 2007;448:561-6.

7. Paez JG, Janne PA, Lee JC, et al. EGFR mutations in lung cancer: correlation with clinical response to gefitinib therapy. Science 2004;304:1497-500.

8. Lindeman NI, Cagle PT, Aisner DL, et al. Updated molecular testing guideline for the selection of lung cancer patients for treatment with targeted tyrosine kinase inhibitors: guideline from the college of American pathologists, the International association for the study of lung cancer, and the association for molecular pathology. 
Arch Pathol Lab Med 2018;142:321-46.

9. Dearden S, Stevens J, Wu YL, et al. Mutation incidence and coincidence in non small-cell lung cancer: metaanalyses by ethnicity and histology (mutMap). Ann Oncol 2013;24:2371-6.

10. Torres-Durán M, Ruano-Ravina A, Parente-Lamelas I, et al. Lung cancer in never-smokers: a case-control study in a radon-prone area (Galicia, Spain). Eur Respir J 2014;44:994-1001.

11. World Health Organization. WHO handbook on indoor radon: a public health perspective. Geneva: World Health Organization, 2009.

12. Rudin CM, Avila-Tang E, Harris CC, et al. Lung cancer in never smokers: molecular profiles and therapeutic implications. Clin Cancer Res 2009;15:5646-61.

13. Sun S, Schiller JH, Gazdar AF. Lung cancer in never smokers--a different disease. Nat Rev Cancer 2007;7:778-90.

14. Burton C, Dan Y, Donovan A, et al. Urinary metallomics as a novel biomarker discovery platform: breast cancer as a case study. Clin Chim Acta 2016;452:142-8.

15. Zheng J, Chen B, Liu R, et al. Detection of urinary trace elements and pattern recognition analysis in patients with renal cell carcinoma by inductively coupled plasma mass spectrometry. J Cancer Res Ther 2018;14:S1152-7.

16. Shimizu Y, Dobashi K. Proton ion-microbeam elemental analysis for inhaled particle-induced pulmonary diseases: application for diagnosis and assessment of progression. Curr Med Chem 2013;20:789-93.

17. Terakawa A, Ishii K, Matsuyama S, et al. Concentration of cisplatin-incorporated polymeric micelles in a murine solid tumor evaluated using PIXE analysis. Int J PIXE 2014;24:41-7.

18. Terakawa A, Ishii K, Matsuyama S, et al. Effects of a vascular disrupting agent for cancer treatment on normal tissue evaluated by PIXE analysis using quantum dots. Int J PIXE 2014;24:59-65.

19. Whitcombe D, Theaker J, Guy SP, et al. Detection of PCR products using self-probing amplicons and fluorescence. Nat Biotechnol 1999;17:804-7.

20. Yoshida K, Yatabe Y, Park JY, et al. Prospective validation for prediction of gefitinib sensitivity by epidermal growth factor receptor gene mutation in patients with non-small cell lung cancer. J Thorac Oncol 2007;2:22-8.

21. Sera K, Yanagisawa T, Tsunoda H, et al. Bio-PIXE at the Takizawa facility (Bio-PIXE with a baby cyclotron). Int J PIXE 1992;2:325-30.

22. He X, Shen $H$, Chen $Z$, et al. Element-based prognostics of occupational pneumoconiosis using micro-protoninduced X-ray emission analysis. Am J Physiol Lung Cell Mol Physiol 2017;313:L1154-63.

23. Gaur S, Agnihotri R. Health effects of trace metals in electronic cigarette aerosols-a systematic review. Biol Trace Elem Res 2019;188:295-315.

24. Taga M, Mechanic LE, Hagiwara N, et al. EGFR somatic mutations in lung tumors: radon exposure and passive smoking in former- and never-smoking U.S. women. Cancer Epidemiol Biomarkers Prev 2012;21:988-92.

25. Mezquita L, Olmedo ME, Ruano-Ravina A, et al. Is there any role for residential radon in patients with nonsmall-cell lung cancer (NSCLC) harbouring molecular alterations? Preliminary results. J Thorac Oncol 2015;10:S303-4.

26. Ruano-Ravina A, Torres-Duran M, Kelsey KT, et al. Residential radon, EGFR mutations and ALK alterations in never-smoking lung cancer cases. Eur Respir J 2016;48:1462-70

27. Toyokuni S. Role of iron in carcinogenesis: cancer as a ferrotoxic disease. Cancer Sci 2009;100:9-16.

28. McDonald AD, McDonald JC, Pooley FD. Mineral fibre content of lung in mesothelial tumours in North America. Ann Occup Hyg 1982;26:417-22.

29. Lewis CG, Belniak RM, Plowman MC, et al. Intraarticular carcinogenesis bioassays of CoCrMo and TiAlV alloys in rats. J Arthroplasty 1995;10:75-82.

30. De Boeck M, Lardau S, Buchet JP, et al. Absence of significant genotoxicity in lymphocytes and urine from workers exposed to moderate levels of cobalt-containing dust: a cross-sectional study. Environ Mol Mutagen 2000;36:151-60.

31. Di Bucchianico S, Gliga AR, Akerlund E, et al. Calciumdependent cyto- and genotoxicity of nickel metal and nickel oxide nanoparticles in human lung cells. Part Fibre Toxicol 2018;15:32.

32. Oller AR, Costa M, Oberdorster G. Carcinogenicity assessment of selected nickel compounds. Toxicol Appl Pharmacol 1997;143:152-66.

33. Kasprzak KS, Sunderman FW Jr, Salnikow K. Nickel carcinogenesis. Mutat Res 2003;533:67-97.

34. Theophanides T, Anastassopoulou J. Copper and carcinogenesis. Crit Rev Oncol Hematol 2002;42:57-64.

35. Richardson-Boedler C. Metal passivity as mechanism of metal carcinogenesis: chromium, nickel, iron, copper, cobalt, platinum, molybdenum. Toxicol Environ Chem 2007;89:15-70.

36. Gumulec J, Masarik M, Adam V, et al. Serum and tissue 
Zinc in epithelial malignancies: a meta-analysis. PLoS One 2014;9:e99790.

37. Catalani S, De Palma G, Mangili A, et al. Metallic elements in lung tissues: results of a meta-analysis. Acta Biomed 2008;79:52-63.

38. Ballmaier D, Epe B. Oxidative DNA damage induced by potassium bromate under cell-free conditions and in mammalian cells. Carcinogenesis 1995;16:335-42.

39. Barry KH, Koutros S, Lubin JH, et al. Methyl bromide exposure and cancer risk in the Agricultural Health Study. Cancer Causes Control 2012;23:807-18.

40. Zabłocka-Słowińska K, Płaczkowska S, Prescha A, et al. Serum and whole blood $\mathrm{Zn}, \mathrm{Cu}$ and $\mathrm{Mn}$ profiles and their relation to redox status in lung cancer patients. J Trace Elem Med Biol 2018;45:78-84.

41. Bernhard D, Rossmann A, Wick G. Metals in cigarette smoke. IUBMB Life 2005;57:805-9.

42. Badea M, Luzardo OP, Gonzalez-Antuna A, et al. Body burden of toxic metals and rare earth elements in non-

Cite this article as: Chiba R, Morikawa N, Sera K, Ishida K, Nagashima H, Shigeeda W, Deguchi H, Tomoyasu M, Hosokawa T, Saito H, Sugai T, Yamauchi K, Maemondo M. Elemental and mutational analysis of lung tissue in lung adenocarcinoma patients. Transl Lung Cancer Res 2019;8(Suppl 3):S224-S234. doi: 10.21037/tlcr.2019.08.18 smokers, cigarette smokers and electronic cigarette users. Environ Res 2018;166:269-75.

43. Şahin M, Karayakar F, Erdogan KE, et al. Liver tissue trace element levels in HepB patients and the relationship of these elements with histological injury in the liver and with clinical parameters. J Trace Elem Med Biol 2018;45:70-7.

44. Asker S, Asker M, Yeltekin AC, et al. Serum levels of trace minerals and heavy metals in severe COPD patients with and without pulmonary hypertension. Int J Chron Obstruct Pulmon Dis 2018;13:1803-8.

45. Mao C, Qiu LX, Liao RY, et al. KRAS mutations and resistance to EGFR-TKIs treatment in patients with nonsmall cell lung cancer: a meta-analysis of 22 studies. Lung Cancer 2010;69:272-8.

46. Zheng D, Wang R, Zhang Y, et al. The prevalence and prognostic significance of KRAS mutation subtypes in lung adenocarcinomas from Chinese populations. Onco Targets Ther 2016;9:833-43. 


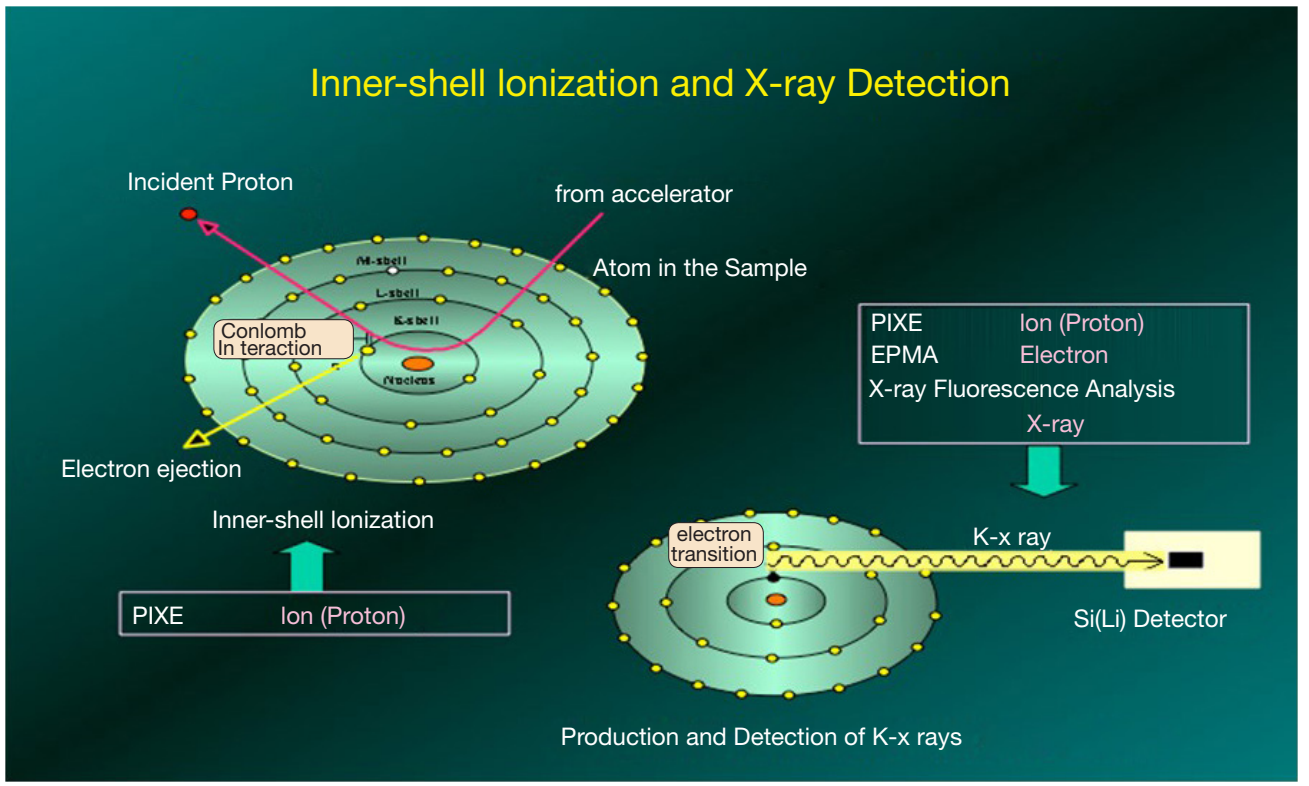

Figure S1 Mechanism of a PIXE system. PIXE, particle-induced X-ray emission.

Table S1 Patient characteristics of KRAS mutation

\begin{tabular}{|c|c|}
\hline Characteristics & KRAS mutation $(n=32)$ \\
\hline Age (years), median [range] & $75.1[60-80]$ \\
\hline \multicolumn{2}{|l|}{ Sex } \\
\hline Female & 11 \\
\hline Male & 21 \\
\hline \multicolumn{2}{|l|}{ Smoking history } \\
\hline Never & 10 \\
\hline Ever/current & 22 \\
\hline \multicolumn{2}{|l|}{ Stage } \\
\hline $1 / 2$ & 31 \\
\hline $3 / 4$ & 1 \\
\hline \multicolumn{2}{|l|}{ Mutation type } \\
\hline G12C & 6 \\
\hline $\mathrm{G} 12 \mathrm{C}+\mathrm{G} 13 \mathrm{C}$ & 1 \\
\hline G12D & 6 \\
\hline G12V & 9 \\
\hline G12A & 5 \\
\hline G13C & 2 \\
\hline G13D & 1 \\
\hline G59G & 1 \\
\hline $\mathrm{G} 61 \mathrm{H}$ & 1 \\
\hline
\end{tabular}

